\title{
Social sustainability in certification schemes for biofuel production: an explorative analysis against the background of land use constraints in Brazil
}

\author{
Anna Mohr ${ }^{1}$ and Linda Bausch ${ }^{2^{*}}$
}

\begin{abstract}
Background: This article examines the scope of voluntary certification schemes, based on the sustainability criteria of the European Renewable Energy Directive for biofuel production in the context of social sustainability and land use issues in Brazil. Possibilities and limitations of such certification schemes are discussed against the background of the rapid-changing Brazilian agricultural sector.

Methods: Brazil was chosen as a case study being both one of the first countries where ethanol certification projects are implemented and a potential certified ethanol-exporting country. To capture social effects concerning land use connected to an increased ethanol production, semi-structured expert interviews were conducted within an explorative approach in São Paulo in the years 2011 and 2012. The study addresses the following question: what is the scope of certification concerning social sustainability in the light of a rising demand on agricultural land?

Results: An increasing demand for biofuels and other agricultural goods, as cash crops, leads to a concentration process of agricultural production. Land price hikes in infrastructural well-connected agricultural areas and the uneven distribution of land in Brazil are leading to newly arising negative effects on social sustainability. We assume that certification schemes have a limited scope in the above mentioned environments.

Conclusions: As the scale of certification schemes is based on production-chain-governance, indirect and macro effects concerning social sustainability in Brazil cannot be addressed by this instrument. Hence, there is a strong need for comprehensive public regulation on land use issues on a national and international level in order to flank land use concentration in dynamic agricultural sectors, such as the Brazilian one.
\end{abstract}

Keywords: Voluntary certification schemes, Social sustainability, Land use dynamics, Ethanol, Brazil

\section{Background}

The rising large-scale plantations for main energy, fodder and food commodities such as soy, palm oil and sugar cane have led to controversial discussions about the sustainability of such developments and negative impacts on the ecological and social scale. The debates led to the development of so-called sustainability schemes, either developed in open multi-stakeholder initiatives or private industry-driven processes, containing socioecological criteria.

\footnotetext{
* Correspondence: linda.bausch@ufz.de

${ }^{2}$ Department Bioenergie in Kooperation mit dem Department

Bioenergiesysteme des Deutschen Biomasseforschungszentrums

gemeinnützige GmbH (DBFZ), UFZ - Helmholtz Zentrum für Umweltforschung,

Torgauer Straße 116, Leipzig 04347, Germany

Full list of author information is available at the end of the article
}

The European demand for biofuels as well as the sustainability criteria, which are integrated into the European Renewable Energy Directive (EU RED), may have an impact on the agricultural production sites outside the Union. The question is how this quantitative demand as well as the qualitative regulation through the sustainability criteria implemented through certification will influence this kind of development. The sustainability criteria, which are coupled to the directive, only comprise the ecological dimension [1]. In order to tackle social sustainability aspects, the European Commission has to report on production patterns of biofuels, food prices and security, indirect land use change and land use rights, social inclusion and labour conditions amongst other issues [1-3]. 
Certification schemes for biofuel production, on the one hand, can be seen as an avant-garde initiative for a responsible production of agricultural goods. On the other hand, critics claim that the certification schemes neither address properly socioecological aspects of agricultural mass production nor are indirect effects such as indirect land use change (ILUC) and displacement effects formulated that are happening outside of the production chain [4-10]. A large spectrum of literature and discussions can be found in the field of environmental certification and standard setting which cannot be outlined in its full extent. Nevertheless, some main lines of development within the debate shall be mentioned. One of the first global environmental certification initiatives was the Forest Stewardship Council established in 1993. The certification of single agricultural products and production chains followed this development, such as coffee, cacao and fish, as the notion of a responsible consumer emerged in industrialised countries. This development is, for example, drafted by Cashore et al., Taylor and Muradian and Pelupessy [11-13]. In Europe, the debates about standard setting in the field of energy crops turned up in $2006 / 2007$, e.g. through special commissions that published reports as the one by Cramer et al. [14]. At the beginning, the topics around standards in literature were mainly marked by technical aspects and organisation of production chains, e.g. as outlined by Kaplinsky and Morris, Gereffi et al. and Humphrey [15-17]; the debates are now coined by governance issues and newly arising modes of global governance through non-state market actors. These issues are treated, e.g. by Ponte et al., Brassett and Tsingou, Büthe, Cashore and Bernstein and Cashore [18-22]. Disciplines like critical geography or political ecology ask more crucial questions about the 'expansion of the certified world' and the neoliberalising of nature as, for example, done by Mutersbaugh et al., Castree and Klooster [23-25]. Authors within these disciplines also broach the issue of power relations that are constituted within such certification schemes, as the constituted northsouth relations in terms of rule setting, trade and control are hardly challenged by these systems $[23,26]$. Against this background, certification schemes are often discussed in the following context: (1) their legitimacy including the involvement of different stakeholders, (2) their definition of sustainability and (3) their scope and effectiveness in guaranteeing the ecological and social sustainability aspects $[7,27-30]$.

This article focuses on the later certification scheme discussion, i.e. the scope of certification schemes, highlighting especially social effects relevant to the consequences of increased production of biofuels and connected land use dynamics in Brazil. The argument herein is centred on the application of certification schemes for the production of biofuels. Based on the articles of German and Schoneveld, Scarlat and Dallemand and van Stappen et al. [7-9], the hypothesis is that certification schemes and the herein anchored sustainability indicators can help narrow down undesired social effects in the production chain as direct effects related to working conditions and security aspects are controlled directly and could lead to an improvement of conditions but might not necessarily address negative social side effects that occur outside the production chain (AM and LB 2011, personal communication). This may come as a result of massive, internal and external demands for biofuels - amongst other agricultural uses such as soy cropping and cattle breeding - and as such, for fertile lands [31-35]. Al-Riffai et al. (2010) in their study on the European Union (EU) and US biofuel mandates highlight that the competition between biofuel crop sectors and other agricultural commodities will have implications for agriculture and land use which has a significant impact on net agricultural exporting countries such as Brazil [36]. Whilst indirect effects such as ILUC effects and their consideration within the sustainability criteria of EU RED are being prominently discussed amongst ecological experts, indirect social effects are not yet addressed by the regulatory boards of the EU [10,37-41]. The Global Bioenergy Partnership, for example, developed a comprehensive criteria catalogue including a wide range of social indicators [42]. The initiative recognises that communities can be displaced and lose access to land if tenure is insecure, and even though these indicators consider a special criteria on land acquisition and tenure, necessary information could be missing [42]. Although these indirect ecological and social effects are closely but complexly interlinked, this article explores only current tendencies of indirect social effects in Brazil due to an increased biofuel production and land concentration, also commented by Teixeira and Miccolis in 2011 in a publication on biofuel expansion in Brazil [43] or described by Mendonça (also in 2011) on ethanol production in the state of São Paulo [44]. The analyses of the scope of certain biofuel certification schemes within the changing agricultural sector in Brazil and connected land use dynamics will allow us (1) to get a better understanding of the translation of the sustainability criteria into indicators in certain voluntary certification schemes - International Sustainability \& Carbon Certification (ISCC), Bonsucro-Better Sugarcane Initiative (BSI) and Roundtable on Sustainable Biofuels (RSB), (2) to outline the changing structure of the Brazilian ethanol sector and connected land use dynamics, and (3) to understand the governance options and limitations of voluntary certification schemes for biofuels in the case of the Brazilian ethanol production, social sustainability and land use. 


\section{Methods}

Brazil is a country that is especially interesting for this analysis due to its long-time experiences within the sector of bioethanol production, its large production potentials regarding agricultural raw materials, the development of processing technologies and its imposed role as a biofuel producer in the global market. Parallel to that, the usage and distribution of land in Brazil is also coined by a socio-historically grown divide between smallholders and Latifundistas (large estate owners) as well as other land user groups (e.g. indigenous groups, agro-industrial industries, investors) [45]. In the past decade, ethanol production in Brazil almost tripled (ca. 28 Mtoe in 2010), while the area planted with cane doubled (ca. 8 Mha in 2010) [46]. Most of this sugar cane and ethanol production is located at the southeast of Brazil (about 85\%). The state of São Paulo especially appeals to the sugar cane industry because of the good agro-ecological conditions based on suitable soils, climate as well as flat landscapes, and it represents a favourable tenure for industrialised agriculture. Additionally, support by the public sector, the good infrastructure of the region concerning transport, closeness to markets, research centres as well as industrial clusters promoted an expansion of the sugar cane and ethanol industry [32]. Certainly, the agro-ecological conditions are also favourable for other agricultural crops besides sugar cane, and in some regions of São Paulo, e.g. in the municipalities of Pontal do Paranapanema or Ribeirão Preto, agrarian reform settlements are claiming access to land for local food production [44]. Irregular processes of land ownership in these regions have led to land conflicts and to questions of land distribution in between the agrarian settlements who preferably conduct familiar agriculture on the one hand and large-scale agriculture on the other [47]. Due to this social and ecological conditions and the possibility of an ample field stay of the authors, this study will illustrate the perceptions of stakeholders and effects of certification, focusing on social aspects, by means of this exemplification.

The empirical, explorative analysis is based on semistructured interviews. Certified biomass projects are just recently implemented, and impacts will be more visible in the near future. Fifteen key informant interviews of a duration between 1 and $2 \mathrm{~h}$ were conducted during a field stay in Brazil in 2011 and 2012 with representatives of several organisations covering an ethanol and a sugar cane research institute, a certification organisation, a sugar cane company, worker unions, members of social movements, the pastoral movement, a national ecological non-government organisation (NGO) and a global ecological NGO, a university and a development bank. The aim of the interviews was to identify interconnections concerning an increased demand for certified ethanol under the assumption that this demand will rise in the future, including the possible impacts on social sustainability of communities involved or influenced by these production projects. Thereby, the research field has been explored in order to have a better understanding of these connections and to identify further fields of research. The interviews were carried out mainly in the state of São Paulo and, additionally, in the cities and surroundings of Brasilia and Cuiaba. During the analysis of the interviews, emphasis was put on the following aspects: (1) changing structure of the Brazilian ethanol sector due to an increased demand for ethanol, (2) land use dynamics related to an expansion and intensification of sugar cane, and (3) perspective of different land users related to the effectiveness of certification schemes in terms of social and ecological sustainability.

The results from this empirical analysis will be crosschecked with the criteria of relevant certification schemes. These schemes were analysed according to social aspects within the defined criteria, e.g. workers' rights, the interdiction of discrimination or the ban of child work. Additionally, some voluntary certification schemes also include to some extending social effects occurring outside the company level like the interaction with local food security. The study deals with the limits of voluntary certification and constraints where national policies should be introduced to reduce negative effects applied to the ethanol production context in Brazil. For this reason, the authors selected the three voluntary certification schemes ISCC, Bonsucro and RSB as they are accepted by the European Commission to fulfil the EU RED requirements and therefore are based on a political demand; they are results of multi-stakeholder initiatives, contain also social criteria and are mainly discussed to be applied on the sugar cane production sector in Brazil.

The following gives an overview on the selected certification schemes and focuses especially on the social criteria. Subsequently, as the criteria of those schemes interfere with national and regional policies, an introduction of the most influential Brazilian policies follows to frame the political context where certification is implemented.

\section{Results and discussion}

\section{Sustainability criteria in selected voluntary certification schemes}

Due to rising critics during the last years regarding the devastating impacts of large-scale commodity production in the bioenergy and food sector, the so-called sustainability certification schemes were developed in multi-stakeholder processes to secure the compliance with environmental and social minimum criteria. The following section will give an overview on social aspects within the selected certification schemes ISCC, Bonsucro 
and RSB. These certification schemes seem to be the most relevant for the Brazilian ethanol certification market as there were already several pilot tests and, in the case of Bonsucro, certified companies.

\section{Social aspects within the voluntary certification schemes ISCC, Bonsucro, and RSB}

The voluntary certification schemes include some aspects of social sustainability, but their implementation and consideration within the certification process differ widely. As such, this section will see the analysis of how different social aspects are addressed in the certification schemes and their implementation. Finally, it tries to shape the limits of the method, which means that it is of voluntary certification, in influencing in a positive way negative social effects caused by an enhancing biofuel production. Those effects are described as negative social side effects and discussed at the end of this paper. Focus was laid on the three certification schemes ISCC, Bonsucro and RSB - as they are results of multistakeholder initiatives, were accepted to fulfil the EU RED requirements and are mainly discussed to be applied on the production sector in Brazil. Relevance is based on the raw material certification especially of sugar cane for ethanol. For the ISCC and RSB schemes, the focus is on biofuels in general. On that note, companies could choose under which scheme they should be certified. These schemes include direct social criteria mainly based on International Labour Organization (ILO) conventions, such as the freedom of association or forced labour (see Table 1, [48-50]). Additionally, mainly discussed issues regarding biofuel production such as cultivation of energy crops on contested and/or litigated land, consultation with local communities and small holder integration are added to the principles of the RSB and ISCC.

The criteria were divided into social effects on the microscale and social effects on the macro-scale, considering that voluntary certification schemes have a limited scope concerning aspects outside farm level such as food security or a rising demand for agricultural land. As these aspects are also shaped by national and regional legislations, the next section will give an overview on the Brazilian context and respective legislations and ordinances concerning social aspects. Besides the fact that direct social criteria are mainly listed in the three analysed schemes (see Table 1), the indirect social aspects (e.g. displacement effects due to higher land prices, hindrance of access to land) are considered unequal within ISCC, Bonsucro and RSB. Differences occur as to the minimum age of employment and the protection of rights of indigenous people, which for example are not part of the ISCC certification scheme. Concerning the minimum age of employment, the RSB ranges from 14
Table 1 Evaluation of social effects in selected certification scheme sources (compiled by the authors)

\begin{tabular}{lccc}
\hline Certification schemes & RSB & ISCC & Bonsucro \\
\hline Compliance with labour laws & Yes & Yes & Yes \\
Land rights & Yes & Yes & Yes \\
Forced labour & Yes & Yes & Yes \\
Child labour & Yes & Yes & Yes \\
Worker health and safety & Yes & Yes & Yes \\
Discrimination & Yes & Yes & Yes \\
Minimum wages & Yes & Yes & Yes \\
Freedom of association and collective & Yes & Yes & Yes \\
bargaining & & & \\
Legal contract situation & Yes & Yes & Yes \\
Consultation with local community & Yes & Yes & - \\
No contested land & Yes & Yes & - \\
Adaptation for small holder certification & Yes & Yes & - \\
Indigenous people & Yes & - & - \\
Social Impact Assessment & Yes & Yes & - \\
Food security & Yes & Yes & - \\
International treaties on land & Yes & Yes & Yes \\
Rural unemployment & Yes & - & - \\
\hline
\end{tabular}

${ }^{a}$ Refers to local food security.

to 15 years without making a difference whether it is about non-hazardous work or not. Bonsucro and ISCC consider hazardous work. In both cases, minimum age for employment is 15 for non-hazardous work and 18 for hazardous work. Vogelpohl and Hirschl investigated the certification schemes on the availability of food and the consideration of land use rights [28]. Food security is only mentioned within the schemes of ISCC and RSB and refers to local food security, indicating therefore the non-interference of biomass provision in stable food crop production $[48,49]$. In the case of RSB, only areas and regions with food emergencies are considered [49].

All certification schemes mention the compliance of existing land use rights. For instance, the ISCC standard claims that 'The producer can prove that the land is used legitimately and that traditional land rights have been secured' [48]. However, in this case, the problem is not the consideration of the aspect 'land use rights' within the schemes but the unclear or non-regulated land use rights in the producing country, e.g. in Brazil. In the case of certification, a correct implementation is not possible due to the latter assertion. Some criteria demand high requirements from the operators implementing a standard, e.g. the RSB criterion $2 \mathrm{~b}$ which states that 'Free, prior [and] informed consent (FPIC) shall form the basis for the process to be followed during all stakeholder consultation, which shall be gender sensitive and result in consensus-driven negotiated agreements' or principle 5 
which states that 'In regions of poverty, biofuel operations shall contribute to the social and economic development of local, rural and indigenous people and communities' [49]. It is quite questionable if operators focusing on economic viability are able and willing to fulfil such demanding criteria. In this case, an operator would need guidance and support to achieve compliance with the principle. The same applies for the 'participatory social impact assessment' required for ISCC and RSB where own expertise of the operator to conduct the assessment cannot be taken for granted. The RSB states in its preface that voluntary certification schemes, which focus on the individual operator, cannot cover indirect effects caused by rising biofuel production: 'Voluntary certification alone may not be the best tool to address indirect impacts, since these macro-level impacts are likely to be beyond the control of the individual farmer or biofuel's producer seeking certification' [49]. Therefore, the RSB admits that the criteria aim to address only the direct activities that farmers and producers can undertake to prevent unintended consequences from biofuel production. That is why the scope of certification has to be determined and clearly delimited. Where are the limits of certification and where do national policies have to be applied in order to determine social development effects?

\section{Social aspects within Brazilian policy initiatives}

An important background for the analysis of the social outcomes of biofuel production in spite of certification is an examination of the social and environmental policies of the country, in this case Brazil, as they have to be complied if the operator aspires certification. Labour rights are legally based on 'The Consolidation of Labour Laws' (Consolidação das Leis do Trabalho) tackling principal subjects such as registration/labour card, period of recreation, occupational safety, organisation into worker unions or inspection. Brazil has ratified most of the ILO core conventions except Convention 87 on freedom of association and protection of the right to organise (see Table 2, [51]).

Added to the national labour laws, there are several public and private self-regulating initiatives agreed on between the industry sector, the government and social society. Important to cite is the 'Dirty List' which lists natural persons and legal entities, such as producing companies, which were caught flagrantly, keeping workers in conditions analogous to slavery. These persons or entities are published in the list and are economically punished. Companies and individuals on the list cannot receive public financing, and there is no rural credit concession. The 'National Compact for the Eradication of Slavery Work' launched by ILO and supported by the local NGOs Instituto Ethos, Social
Observer Institute and Reportér Brasil obligates companies on a voluntary basis to control their retailers on exploitation of their workers in conditions analogous to slavery [52]. This instrument is foremost a market based pressurising medium for companies continuing their production on the basis of slavery work. Those companies, producing under slavery conditions, are published on the mentioned dirty list.

The National 'Agreement on Improvement of Labour Conditions of the Sugarcane Production' is based on a multi-stakeholder dialogue between the government, workers and employers [53]. The objective of this round table, installed in 2008, was to debate and recommend solutions for a more human and secure manual sugar cane harvest. Furthermore, the target is to find solutions for the reincorporation of workers on the labour market in the light of an increasingly mechanised harvesting process.

The existence of those initiatives shows that there is a consciousness on social implications in the sector as well as voluntary commitments. Certification, as a private control tool, can be a tool to enforce the compliance of existing legislation, audited through a private accredited company. In this regard, issues concerning direct working conditions such as an existing contract, labour health or slavery analogous work (listed in Table 2) will be directly controlled by the auditor, if the corresponding operator aims for a sustainability label. Thereby, certification could improve the enforcement of an already comprehensive social legislation if there is enough commitment by the company (AM and LB, interview 15 May 2011). According to ILO recommendations, Brazil would need about 5,000 inspectors supervising the labour market [54]. Currently, there are only 3,000 inspectors active in this field. In this case, direct monitoring through a yearly audit could enforce the improvement of social conditions on the production site.

In the analysis of the case study of Brazil, the national political-historical context concerning biofuel production and the effects of biofuel production on social implications in spite of certification are combined. The argument hereto is that there are several indirect effects caused by a rising biofuel production, which cannot be reached through sustainability certification alone. These effects root in the overall economic-political development process of Brazil and are enforced by a rising pressure on the outputs of agricultural production. The claim therefore is that the pressure on agricultural land enforced by the expansion of energy crops for fuels and combined with other agricultural expansion tendencies, e.g. beef and soy production, aggravates displacement effects and restricts the already narrow access to land in a country with one of the highest inequalities in land distribution in the world. The following section will give an 
Table 2 ILO core conventions ratified by Brazil in 2011

\begin{tabular}{|c|c|c|}
\hline \multicolumn{2}{|l|}{ Core convention } & \multirow{2}{*}{ Ratified (and enforced) } \\
\hline Freedom of association and collective bargaining & $\begin{array}{l}\text { C87 Freedom of Association and Protection of the Right to Organize } \\
\text { Convention, } 1948\end{array}$ & \\
\hline & C98 Right to Organize and Collective Bargaining Convention, 1949 & 18 Nov 1952 \\
\hline \multirow[t]{2}{*}{ Elimination of forced and compulsory labour } & C29 Forced Labour Convention, 1930 & 25 April 1957 \\
\hline & C105 Abolition of Forced Labour Convention, 1957 & 18 June 1965 \\
\hline \multirow{2}{*}{$\begin{array}{l}\text { Elimination of discrimination in respect of employment } \\
\text { and occupation }\end{array}$} & C100 Equal Remuneration Convention, 1951 & 25 April 1957 \\
\hline & C111 Discrimination (Employment and Occupation) Convention, 1958 & 26 Nov 1965 \\
\hline \multirow[t]{2}{*}{ Abolition of child labour } & C138 Minimum Age Convention, 1973 & 28 June 2001 \\
\hline & C182 Worst Forms of Child Labour Convention, 1999 & 02 Feb 2000 \\
\hline
\end{tabular}

overview on the Brazilian ethanol sector, current land use dynamics and the different perspectives on the scope of certification schemes concerning sustainability. This section will see the application of social criteria on the background of the ethanol sector in the state of São Paulo.

Case study of Brazil and São Paulo: changing structure of the ethanol sector, land use and social dynamics and perspectives from different actors on certification schemes

The implementation of socioecological certification has to be examined in the political-historical context of the country. Subsequent to the previous section, this section has the intention to describe the agricultural context in which the voluntary certification is embedded. A rising demand on energetic biomass, even though coupled to socioecological criteria, has to be regarded against this background. Even though, currently, little ethanol is exported to the EU under the RED requirements (see Table 3, [55-58]), interview statements from along the production chain affirm that the sector is expanding and companies are also getting prepared to receive one of the mentioned certification schemes. The first shipment of Bonsucro certified ethanol from Brazil arrived in November 2012 at the port of Rotterdam [59].

Current socio-economic trends will be described as well as the current land use and social dynamics that are related to an expansion and intensification of the agricultural sector. Finally, the interviews are evaluated according to the perception of certification of different actors, and possible direct and indirect social effects will be stated.

\section{Changing structure of the Brazilian ethanol sector}

Brazil has currently reached the position of second largest ethanol producer of the world just after the USA $[60,61]$. Brazil reached a national blending quote for ethanol of $20 \%$ to $25 \%$, which was reduced in the last 2 years due to a current production crisis. The overall ethanol production in the year 2008 was of 27 billion litres, from which approximately $90 \%$ was used for the Brazilian internal market while more than $10 \%$ of the production was exported to the USA and Europe [62]. Due to a booming internal market for ethanol combined with adverse climate conditions for sugar cane cropping, the ethanol exports were reduced to less than two billion litres in 2010 [63]. As the demand for biofuels is rising globally [64], disregarding the decrease in 2010 because of the financial crisis, the worldwide demand for renewable fuels has an impact on the use of agricultural land and the land price hikes in Brazil amongst other drivers. Concerning this issue, representatives of the social movement, the sugar cane research centre and the national ecological NGO, state that sugar cane expansion is leading to land price hikes in São Paulo and therefore to an increasing pressure on land use (AM and LB, interviews 6 May 2011, 10 May 2011 and 19 May 2011). Fernandes et al. explain that the amount of sugar cane-planted areas in the São Paulo state increased by $62.3 \%$ (2003/2004 to 2008/ 2009); in most dynamic regions, planted areas increased up to $180.3 \%$ (Presidente Prudente) and 128.4\% (Araçacatuba) [65]. According to discussions at the certification body meeting, the statements of the sugar

Table 3 Total ethyl alcohol export from Brazil to EU from 2009 to 2012 in 1,000 m

\begin{tabular}{lcccc}
\hline & April 2008 to March $\mathbf{2 0 0 9}$ & April $\mathbf{2 0 0 9}$ to March $\mathbf{2 0 1 0}$ & April $\mathbf{2 0 1 0}$ to March $\mathbf{2 0 1 1}$ & April $\mathbf{2 0 1 1}$ to March $\mathbf{2 0 1 2}$ \\
\hline Ethyl alcohol $^{1}$ & 15.4 & 0.1 & - & 0.1 \\
Ethyl alcohol $^{2}$ & 1274.8 & 801.4 & 356.0 & 94.3 \\
Ethanol in blends & - & 156.3 & 178.2 & 160.4 \\
Total export to EU & 1290.2 & 957.8 & 534.2 & 254.8 \\
\hline
\end{tabular}

${ }^{1}$ Denatured, all strengths; ${ }^{2}$ Undenatured, at least $80^{\circ}$ strength. 
cane and ethanol research institutes, national and global ecological NGOs, it is not primarily the European market which is driving such land use dynamics through an increased demand for ethanol. The main driver for such a rising demand would be the rapidly growing internal market of Brazil as well as the US American and Chinese market (AM and LB, interviews 5 May 2011, 10 May 2011, 19 May 2011, 20 May 2011 and 1 June 2011). The sugar cane producer (AM, interview 15 May 2011) affirms a rising interest to sell socioecological certified raw materials on a stable and high price market. Nevertheless, a representative from the national ecological NGO said that 'The demand for [biofuels] inside the country is actually increasing and that is why we have the effect of land price hikes (...). I think that the European demand still influences the land prices, the demand for biofuels and the expansion of energy crops [in Brazil]. Parallel to the rising demand for ethanol on the internal market, the European and the Chinese demand are also increasing. It is not possible to look at these developments disconnectedly' (AM and LB, interview 19 May 2011). This means that the different agricultural markets should not be analysed in a linear and isolated way but rather the correlation between the production of agricultural goods and economic interests.

However, the rising demand for biofuels did not lead to an increased production in Brazil immediately. Due to the economic and financial crisis in 2008/2009, a lot of family-owned sugar cane and ethanol companies suffered from a lack of investment. That led to the situation that the Brazilian industry could not bail out the full production potentials for ethanol. Furthermore, the crisis led to a changed production structure in Brazil due to an increase of foreign investments and joint ventures with transnational companies (LB, interview 1 June 2011). These tendencies are also outlined by other interview partners. Participants of the certification body meeting, representatives of the social movement, the sugar cane as well as the ethanol research centre explained that enormous dynamics and changes are leading to a new structure of the Brazilian ethanol sector. Aspiring for new global markets in the field of renewable energy, smaller enterprises got dragged by transnational companies. Multinational petrol companies entered the ethanol market, e.g. Shell, established Raízen, a joint venture with the biggest Brazilian sugar company COSAN, and gained the Bonsucro certificate in 2011 for its ethanol production [66]. A new line up of enterprises, company strategies as well as investment process has been started (LB, interviews 1 June 2011, 5 May 2011, 6 May 2011 and 10 May 2011). Foreign investments into the sector have begun to rise sharply during the last decade leading to a concentration of firms which are dominating the ethanol-producing sector [67]. At the beginning of 2008/2009, about 40 firms were controlling about $50 \%$ of the ethanol production in Brazil. This variety is supposed to be reduced to six to eight firms, and smaller entrepreneurs will not be able to compete in this business within the next 10 years (LB, interview 1 June 2011) [67]. The social integration of small farmers into these large-scale value chains of agricultural raw materials for biofuels has so far not occurred. Sugar cane is primarily produced in large-scale systems, where smallholders merely participate either by selling their production or renting their land to the local sugar refinery [68].

\section{Land use and social dynamics related to an expansion and intensification of sugar cane}

Besides the trend of multinationalisation of the Brazilian sugar cane and ethanol industry, it is expected that the changed sector will recover from the recession due to the external money influx so that the production capacities will increase again as the market exists. New cooperation between Brazilian and foreign investors such as joint venture Raizen Energia S.A. of the Dutch petroleum company Shell and the biggest Brazilian sugar producer COSAN announced to produce four billion litres of ethanol until 2014 [44], partly certified by the Bonsucro label [50]. The projected potentials for ethanol production in Brazil are high. In a report of the Brazilian Centro de Gestão e Estudos Estratégicos, the possibility of substituting $10 \%$ of the whole global ethanol demand by 2025 was evaluated. A substitution of this kind would lead to a production of 205 billion litres of ethanol in 2025 and an additional 24 million hectares of land for sugar cane cultivation [69]. This increased production could be met through three means: the expansion of sugar cane plantations, the intensification of cultivation and technological innovations. Connected to that, the interview partners in Brazil were asked about the aspects of land use dynamics related to an expansion and intensification of sugar cane.

A representative of the Brazilian sugar cane research centre has expressed that, currently, the price for fertile land in the state of São Paulo is increasing enormously (demonstrated in Figure 1). This price development for fertile land would partly be driven by the objections of the sugar and ethanol companies as they would heat up the competition for land due to increased cultivation of sugar cane (LB, interview 10 May 2011). The high value of fertile land in the context of a globally rising demand for agricultural products in logistically well-connected areas leads to an increase of land tenure prices [70,71]. This trend is also illustrated for Brazil in Figure 1 and São Paulo in Figure 2. 


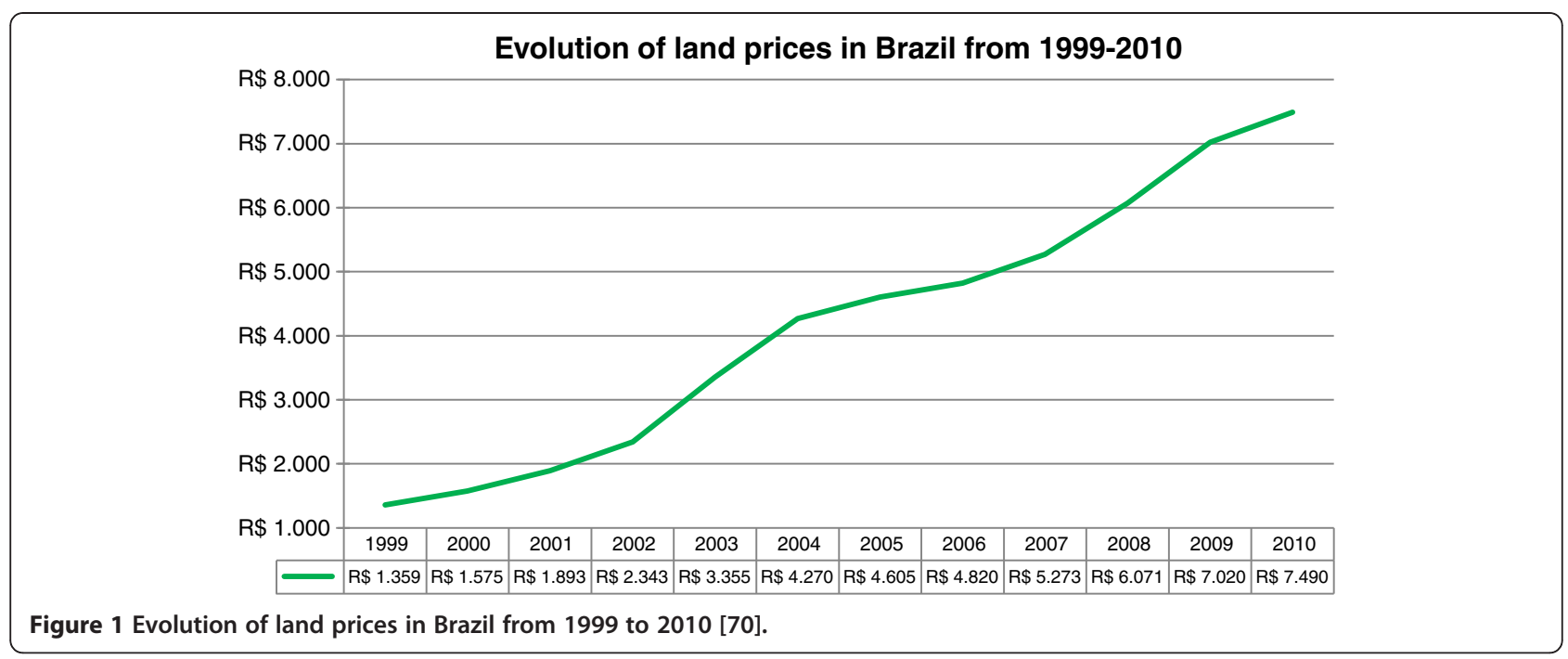

The evolution of land prices for agricultural production in Brazil rose drastically in 10 years from about $\mathrm{R}$ $\$ 1.575 /$ ha in the year 2000 to up to $R \$ 7.490 /$ ha in 2010, which means that prices increased almost fivefold in 10 years. Due to large investments in the main agricultural commodities such as soy, sugar cane and beef, land prices have exploded, as in Aripuanã in the state of Mato Grosso, where the price of unimproved land in more remote areas doubled from $\mathrm{R} \$ 170 / \mathrm{ha}$ to $\mathrm{R} \$ 350 / \mathrm{ha}$ [72].

Regarding the land price evolution for the sugar cane booming state of São Paulo for the available data set between 2001 until 2008, the price for 1 ha of land was nearly fourfold in 8 years until it reached $\mathrm{R} \$ 11,840 /$ ha in 2008.

However, the problem in Brazil would not be a lack of land in order to enlarge the production of sugar cane, soy or corn as expressed by the representative of the ethanol research centre (LB, interview 1 June 2011).
With the right political incentives, the area of cattle breeding and pasture could be used much more efficiently than the current case. The obstacle would be the effective regulation of land use. He states, 'We need to have (...) control, for example to avoid cases like Ribeirão Preto [in the state of São Paulo], where we have $90 \%$ of the area in a municipality with sugar cane. First, because this is illegal (...). Second, because for sure this is not good for biodiversity' (ibid.). The interview partner of the national ecological NGO also confirms this statement. It would indeed be possible to double or triple agricultural production without the need to deforest through a more efficient use of areas as, for example, through the intensification of cattle breeding. However, in reality, this would not happen for several reasons. One reason would be the lack or rather the contradictory incentives set by politics for a more sustainable and efficient use of land as well as the lack of access to technical

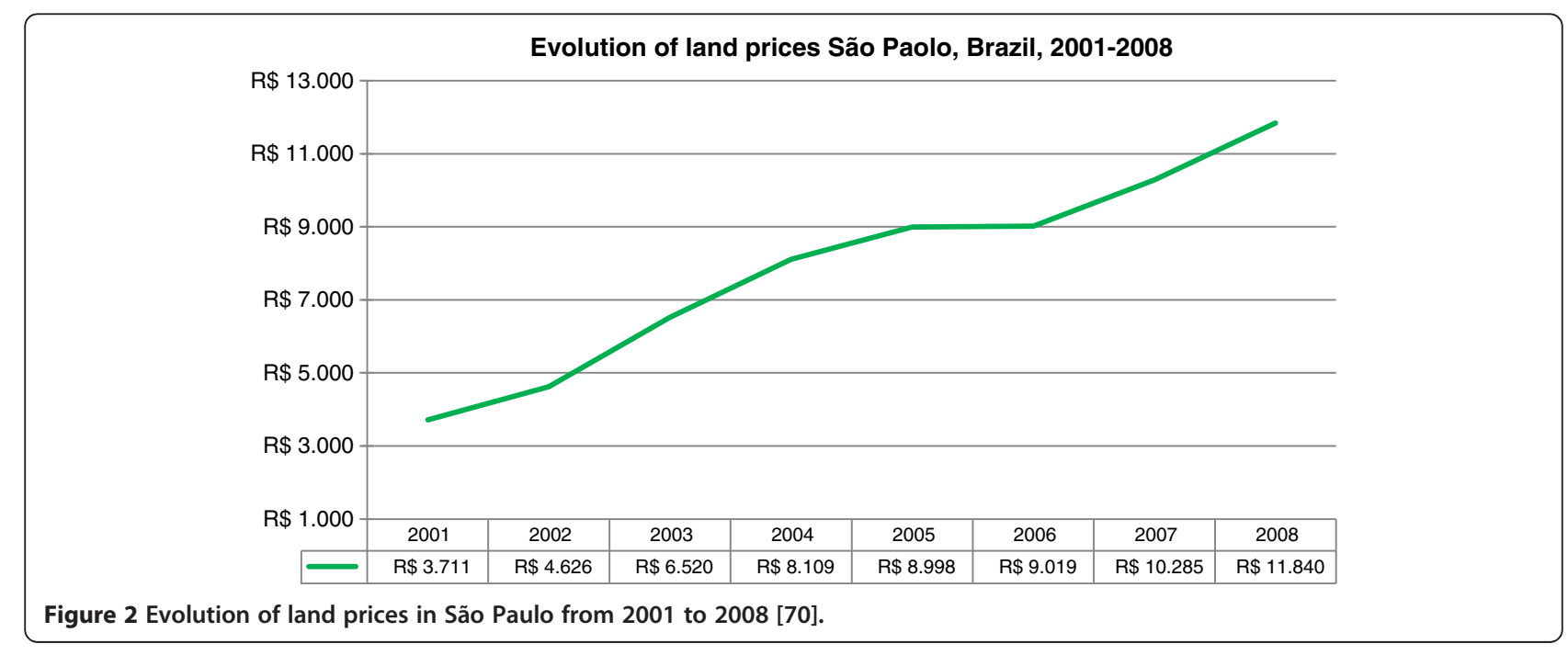


assistance and investments for many farmers. Hence, catthe farming would continue to be very ineffective, and the agricultural sector would continue to open up new areas. Finally, it would be the decision of an individual what and where to cultivate agricultural products. She explains, 'If someone already is a producer (...) in Mato Grosso, it is very difficult to expand in Goias because the producer is already in Mato Grosso. (...) When we start with politics on a macro level, it is easy to think that it is possible to extend any area of agriculture - soy, sugar cane or any other product - without displacement effects. But this is not what happens in reality because, finally, it is a decision on a micro-level' (AM and LB, interview 19 May 2011).

These arguments show that although Brazil owns large territories, agricultural use of fertile lands could lead to unsustainable practices in specific areas, which means that effective instruments and regulations to implement protective laws for land use are needed but, so far, not always real due to different political structures and mechanisms in the Brazilian states. Although Brazil is a country of immense size and area, land issues will also have to be analysed from a land user's perspective instead of only focussing on a statistical macro-perspective on land availability. This holds true also for private regulation via certification, which is implemented in this agricultural reshaped context. Without a strong political framework on land issues and its controlled implementation, private control is not an effective instrument to control indirect land use change or indirect impacts on the social scale. Some of the land users, like the peasant social movement in Ribeirão Preto, state that the land price hikes would lead to a hindrance of the access to land and to a deterioration of ecosystem services for the rural population concerning water, soil and biodiversity aspects (LB, interview 6 May 2011). According to them, the ethanol and biodiesel companies in Brazil would use huge areas in order to produce cheap 'green' fuels. However, this kind of agro-industrial production would constrict family farms and enterprises from business development. In the surroundings of Ribeirão Preto, sugar cane plantations and production sites of multinational companies would expand; land prices would increase and hence pressure rural settlements of local small holders (ibid.).

The extremely uneven land tenure has already been a central problem in Brazil before the international agrarian markets literally exploded. The agricultural production is shaped through the overall inequalities and the historical large-scale land acquisition pattern in contrast to small farm ownership. This structure of the rural sector has barely changed since then [73]. The census of agriculture carried out by the Brazilian Institute of Geography and Statistics in 2006 reports a Gini index of land concentration of 0.872 [74]. This tendency of unjust land ownership was further pushed in the last years due to the overall concentration of agricultural production in the hands of few actors as indicated earlier, e.g. in the ethanol sector. In Table 4 [74], the unequal land distribution is also highlighted in total numbers of agricultural and husbandry land properties. Nearly $50 \%$ of the agricultural properties occupy an area under 10 ha and represent only $2.36 \%$ of the total agricultural area. The disparities of the unbalanced land tenure structures in Brazil are further fortified by unclear legislative arrangements. The Pastoral Commission on Land in 2010 declared 1,186 land tenure conflicts in that year with 559,401 people involved [75].

\section{Key factors derived from the changing structure of the ethanol sector and land use dynamics related to the intensification and expansion of sugar cane and further effects}

Naming these four factors, concentration processes in the biofuel sector, rising land prices, lack of effective and respected controlling instruments and regulations, a highly unequal distribution of land and on-going conflicts on land, we argue that there are negative social side effects caused by an increased agricultural production of the main raw materials for biofuels. Such effects are not addressed in and cannot be prevented by the certification schemes. Consequently, this could lead to direct and indirect displacement effects of small farmers as claimed by the national and the global ecological NGO (AM and LB, interviews 19 May 2011, 20 May 2011). The modernisation of the agricultural sector in Brazil already led to such displacement effects in the past and holds true till the present [73]. The problem with such indirect effects on land use from an ecological but also from a social point of view in terms of the scientific discussion is the measurability, the traceability as well as the scale of these effects, which are not easy to locate. This position is underlined by an expert on indirect land use change from a Brazilian university: 'Discussing about ILUC (...), [some sugar cane and ethanol companies] have a programme where they are looking at [the plantations' impacts] $30 \mathrm{~km}$ around the mill's neighbourhood, but you can have effects of this sugar refineries, (...) thousand kilometres away. (...) These indirect effects can even occur in other countries.' (LB, interview 23 May 2011). Indirect effects, especially land use changes, are further promoted due to the linkages in between different agricultural products and the certification obligation for only some of those products and markets. This leads to a distorted production system in Brazil. Whilst the producers that export biofuels and soy to Europe are the ones who achieve to comply with the principles and criteria of certification, the producers that cannot fulfil 
Table 4 Land distribution in Brazil (2006)

\begin{tabular}{lcccc}
\hline Units of total area & Number of settlements (units) & Percentage & Area of settlements (ha) & Percentage \\
\hline$<10$ ha & $2,477,071$ & 47.86 & $7,798,607$ & 2.36 \\
10 to $<100$ ha & $1,971,577$ & 38.09 & $62,893,091$ & 19.06 \\
100 to $<1,000$ ha & 424,906 & 8.09 & $112,696,478$ & 34.16 \\
1,000 ha and more & 46,911 & 0.91 & $146,553,218$ & 44.42 \\
Total & $5,175,489$ & 100 & $329,941,393$ & 100 \\
\hline
\end{tabular}

these principles will sell their products to the internal or other external markets that do not require such certification. The certified producers would not produce at the agricultural frontier close to the Amazon region in Mato Grosso, where a huge area was deforested in the year 2011, but uncertified ones could continue to use the land (AM and LB, interview 19 May 2011).

\section{Perspective of different land users related to the scope and effectiveness of certification schemes in terms of social and ecological sustainability}

The representatives of the development bank, the global ecological NGO and the ethanol research centre affirm that the European certification efforts are evaluated positively and that certification would have positive effects on the production of agricultural goods in Brazil. A normative change of perception concerning the production of agricultural goods due to the sustainability criteria of the EU RED would be observable mentions the representative of the ethanol research centre (LB, interview 1 June 2011). The debate that is brought into Brazil by the discussion about these sustainability criteria as well as the certification schemes and their indicators would be positive, as what the representative of the global ecological NGO said (AM and LB, interview 20 May 2011). Besides this optimistic perception of the normative value of the sustainability certification efforts that are mainly driven by the EU, the interview partners point out the protective character of the sustainability schemes for the European agrarian market (AM and LB, interviews 20 May 2011, 1 June 2011, 15 May 2011) as well as obstacles with the procedural effectiveness and implementation of these certification schemes as well as their limitations of scope relating to markets, agricultural products and land users. Whilst representatives of the ethanol research centre as well as the global ecological NGO have an optimistic perception of certification as an instrument to foster social and ecological sustainability of agricultural products, the representative of the pastoral movement has a critical view on the normative contribution of certification schemes: '[Certification schemes] are a mode to disguise reality. There is no monoculture production that is not exploiting workers, that is not causing ecological degradation, which does not affect traditional land users, soil and water negatively. (...) [Certification schemes] are a way to ease the consumer's conscience.' (LB, interview 19 September 2012).

As some constraints of the effectiveness of certification schemes and also of other environmental laws and instruments on agricultural production in Brazil, the representatives of the development bank, the sugar cane and ethanol research centre as well as participants from the certification body meeting pointed out the following: (1) corruption, (2) lack of controllability because of mere size of the country, (3) common land clearing practices that are not easy to prevent (land clearing cycle: wood extraction, cattle breeding, agricultural use of land after attainment of an ecological licence), (4) difficulty to monitor criteria of the sustainability schemes for producers because of complexity as well as high costs, e.g. for implementing satellite monitoring ( $A M$ and $L B$, interview 5 May 2011). Concerning the scope of certification schemes relating to the compliance of social and ecological sustainability, the answers of the interview partners can be structured into three types of scope: (1) market, (2) product and (3) stakeholder.

On the level of the market scope, the interview partner of the certification body and of the Brazilian ecological organisation express that Brazil is currently trading agricultural products especially with China, a country that does not claim any certification requirements, and with the USA, which attests a positive GHG balance for Brazilian sugar cane-based ethanol (AM and LB, interviews 5 May 2011, 19 May 2011). As a result, the agricultural production which is certified after the sustainability criteria is very partial at the moment. The representatives of the certification body and of the national ecological NGO therefore express their hopes that the European efforts for certification will give an impulse for other markets and products to follow the example (ibid.).

As for the scope of certification on a product level, the interview partners claim that the effect of a rising awareness concerning sustainable consumption and traceability of production that has been brought in by the sustainability discussion of biofuel production would also have a spill-over effect on other farming products, such as meat (LB, interview 4 May 2011). Nevertheless, some participants of the certification body meeting expressed that the European certification requirements 
would partly be absurd, e.g. because of the distinction in between soy as oil and press cake and connected differing sustainability requirements. Both products would finally be based on the same plant. As the instrument of certification is only focused on some agricultural products, the sustainability criteria would also only partly cover or influence the methods of agricultural production (AM and LB, interview 19 May 2011). The implementation of certification schemes would therefore not impede deforestation but would have the chance to impact on direct social and ecological aspects, as confirmed by the interview partner (ibid.).

On the level of the stakeholder scope, different statements on social effects were outpointed. First, certification schemes would only be relevant for large producers because of the high costs that are connected to its implementation and monitoring (LB, interview 5 May 2011). Therefore, certification schemes and sustainability requirements would also favour agro-industrial production and would be an additional constraint for family farmers who are not able to access this certified market (LB, interview 6 May 2011). Second, the legitimatization of certification schemes and its sustainability criteria would be questionable as not every land user group in Brazil has been consulted in matters of social and ecological sustainability, e.g. the social movement has not been consulted (ibid.). Therefore, participation has not been given (ibid.). Representatives from sugar cane worker unions (AM, interviews 14 to 15 March 2011) referred to the possible effects on farm level. Two out of the three interviewed stated to be sceptical on the positive effects that certification could have on the workers' well-being due to the production model where payment is aligned to production level, which leads to frequent accidents, exhaustion of workers and in worst cases to death. On the one hand, mechanisation would make it easier to fulfil the criteria of a sustainability certificate; on the other, it leads to an unsolved problem of jobless migrant workers in the rural areas of São Paulo (ibid.). Another representative emphasises that national initiatives, such as the mentioned dirty list and the 'National Compact for the Eradication of Slavery Work' had a positive effect on the most precarious working conditions of rural workers, but social criteria of voluntary certification schemes would be hard to fulfil for companies supplying from subcontractors using manual harvesting.

\section{Conclusions}

The worldwide rising demand for biofuels leads to different direct and indirect ecological, social and economic challenges, especially in countries like Brazil where the production of ethanol is an important economic sector. Voluntary biofuel certification, which should avoid negative effects of biofuel production, considers direct ecological and social aspects which are mainly part of the production chain. Examples, therefore, are the compliance with labour laws, minimum wages and minimum age of employment claimed in the criteria catalogue. Disregarding that consideration of these direct social aspects differ within the observed voluntary certification schemes: RSB, Bonsucro and ISCC, it is a first and necessary expandable step to ensure acceptable labour conditions on the basis of international regulations like the core convention of the ILO and the compliance with national laws. In this case, auditing could be an instrument to enforce the application of national laws and serve as a private control tool. On the other hand, it could lead to an enforcement of mechanisation in the sugar cane production sector which leaves an unsolved social problem in rural areas with a huge amount of workless migrant workers. Regarding indirect social effects - e.g. displacement and the hindrance to land access of smaller producers due to land price hikes - the same problem as it occurs with ILUC, namely the dislocation of outcomes, can be predicted. The latter problems connected to biofuel production will gain importance within the next years because of the worldwide rising demand for biomass energy. However, here is the resultant question: will it be possible to limit these indirect social effects of displacement and access to land through certification schemes, land use zonings, social and ecological laws and regulations?

To answer this question more case study research on expanding bioenergy production areas are needed, which would reveal the relation between land use dynamics, social sustainability and possible effects by certification. Questions on the interaction between certification and the enforcement of national laws should be conducted in the near future to enforce evidence of the effectiveness of private control. On behalf of our findings from the explorative analysis on the expanding sugar cane sector in the state of São Paulo, we argue that in order to get control over the rising, complex problems due to an agricultural expansion, there is a strong need for comprehensive public or private regulation and control instruments in the agricultural sector. As presented, land price hikes, especially for fertile and well-connected areas, are and will be a main issue of social concern for specific actors. Nonetheless, as regulation on increased land prices is going beyond the scope of certification, this aspect will have to be addressed via national regulation.

The discussion about voluntary certification of biofuels in Brazil has the chance to make a normative contribution to raise awareness on sustainability issues, which was emphasised by most interview partners. In this regard, a positive development in the discussion on ecological criteria in production chains based on the 
sustainability criteria of the European Directive can be observed. Definitely, it is a first step to integrate questions of ecological sustainability into binding guidelines which will have to be permanently improved and adapted to national policies. It would be positive if social impacts, addressed in voluntary certification schemes, would find their way into the discussion and implementation on workers' rights. While indirect land use change effects on ecosystems and possible calculation methods are currently discussed in most conferences and EU roundtable meetings on sustainability criteria for biofuels, social side effects are hardly mentioned from political decisionmakers in connection with an expanding biofuel production. In the light of rising pressure on arable land, social aspects need to be addressed in decision-making as for example in the RED to foster their implementation into national legislations and in third countries interested to export to the EU or to fulfil any other upcoming sustainability requirement. As there is a clear limit of certification, although it is a starting point for a sustainability discussion, national regulations and control mechanisms have to follow.

Concerning certification with regard to the indirect social side effects, it becomes clear that not all emerging problems of agricultural expansion can be addressed properly by sustainability standards and certification. These problems root in the structure of large-scale agricultural production, oriented towards higher economic output. Indirect ecological and social effects are not only based on the production of raw materials for bioenergy, but are also for the whole industrialised and export oriented agricultural products. As such, there will be no sustainable biofuel sector within an unsustainable agricultural system. Therefore, the discussion on sustainable biofuel production has to be followed by a general discussion on a forward-looking sustainable agriculture, which equally recognises the social and ecological dimensions.

\section{Competing interests}

The authors declare that they have no competing interests.

\section{Authors' contributions}

$A M$ and $L B$ jointly designed the structure of the study and drafted the manuscript. Both authors conducted interviews during their field studies in Brazil in the years 2011 and 2012 and contributed equally to the finalised article. Both authors read and approved the final manuscript.

\section{Authors' information}

LB is a doctoral student at the Department of Bioenergy in cooperation with the Departments Environmental Politics and Conservation Biology of the Helmholtz-Zentrum für Umweltforschung (UFZ) as well as with the Deutsche Biomasseforschungszentrum (DBFZ). She is dealing with the impacts of the European Renewable Energy Directive on socioecological land use issues in Brazil. AM works as a scientific assistant at the Department of Political Sciences at the University of Applied Sciences Bremen. She works to standardize setting processes of biomass certification schemes and their implementation in Brazil. Her doctoral thesis to this topic is supervised by
Prof. Dr. Zimpelmann of the University of Applied Sciences Bremen and Prof. Dr. Michael Flitner of the University of Bremen.

\section{Acknowledgements}

We are grateful to Jörg Kretzschmar from the Deutsche

Biomasseforschungszentrum (DBFZ) for his contribution to this article via the project 'Akzeptanz von Biokraftstoffen', grant FKZ 03KB019B, financed by the Bundesministerium für Umweltschutz, Naturschutz und Reaktorsicherheit. Furthermore, we want to thank our supervisors Prof. Dr. Daniela Thrän, Prof. Dr. Christoph Görg and Prof. Dr. Klaus Henle from the Helmholtz-Zentrum für Umweltforschung (UFZ) and Prof. Dr. Beate Zimpelmann from the University of Applied Sciences Bremen for their comments and support. This work was made possible by the funding from the Helmholtz Association of German Research Centres within the project 'Biomass and Bioenergy systems' and the University of Applied Sciences Bremen. Additionally, the work was supported by the HIGRADE Graduate School. For very useful comments and hints, we would like to thank our colleague Dr. Kwasi Glover. The research periods in Brazil would not have been possible without the support from Dr. Christoph Knogge, Dr. Thomas Püttker, Dr. Pedro Pedro and Giuseppe Campanini. We would like to express our gratitude to them as well as to our patient interview partners. We also want to thank the reviewers of this article for their constructive comments.

\section{Author details}

'GLOKAL Kompetenzzentrum Nachhaltigkeit im Globalen Wandel, Hochschule Bremen, Neustadtwall 30, Bremen 28199, Germany. ${ }^{2}$ Department Bioenergie in Kooperation mit dem Department Bioenergiesysteme des Deutschen Biomasseforschungszentrums gemeinnützige $\mathrm{GmbH}$ (DBFZ), UFZ - Helmholtz Zentrum für Umweltforschung, Torgauer Straße 116, Leipzig 04347, Germany.

Received: 5 March 2013 Accepted: 6 March 2013

Published: 21 March 2013

\section{References}

1. The European Parliament and the Council of the European Union (2012) Directive 2009/28/EC of the European Parliament and of the Council of 23 April 2009: on the promotion of the use of energy from renewable sources. http://eur-lex.europa.eu/LexUriServ/LexUriServ.do?uri=Oj:L:2009:140:0016: 0062:en:PDF. Accessed 21 Sept 2012

2. Maitre E, Meissner Pritchard J (2011) Reporting obligations under the Renewable Energy Directive and the Fuel Quality Directive: an analysis of social sustainability requirements and wider issues. http://www.clientearth.org/reports/ clientearth-briefing-reporting-obligations-renewable-energy-fuel-qualitydirectives-social-sustainability-requirements.pdf. Accessed 21 Sept 2012

3. Levidow L (2013) EU criteria for sustainable biofuels: accounting for carbon, depoliticising plunder. Geoforum 44(1):211-223

4. Soimakallio S, Koponen K (2011) How to ensure greenhouse gas emission reductions by increasing the use of biofuels. Biomass Bioenergy 35(8):3504-3513

5. Frank S, Bottcher H, Havlik P, Valin H, Mosnier A, Obersteiner M, Schmid E, Elbersen B (2012) How effective are the sustainability criteria accompanying the European Union 2020 biofuel targets? GCB Bioenergy. doi:10.1111/ j.1757-1707.2012.01188.x

6. Faria A, Frata A, Bolinauri F, Silvério J, Pizzi P, Azevedo C, de Souza Mamedes J, Biondi A, Gomes M, Glass V, Ishy A, Lopes D (2011) Macro effects in Brazil: the impacts of agroenergy crops in four areas of the country. http://www. reporterbrasil.org.br/documentos/MacroEffects_FinalVersion.pdf. Accessed 21 Sept 2012

7. German L, Schoneveld G (2011) Social sustainability of EU-approved voluntary schemes for biofuels. http://www.cabi.org/cabdirect/FullTextPDF/ 2012/20123035329.pdf. Accessed 21 Sept 2012

8. Scarlat N, Dallemand JF (2011) Recent developments of biofuels/bioenergy sustainability certification: a global overview. Energy Policy 39(3):1630-1646

9. Van Stappen F, Broseb I, Schenkela Y (2011) Direct and indirect land use changes issues in European sustainability initiatives: state-of-the-art, open issues and future developments. Biomass Bioenergy 35(12):4824-4834

10. Hirschl B, Kaphengst T, Neumann A, Umpfenbach K (2012) Science-policy interface and the role of impact assessments in the case of biofuels. In: Raggamby A, Rubik F (ed) Sustainable development, evaluation and policymaking: theory, practice and quality assurance. Edward Elgar, Northampton, pp 151-172 
11. Cashore B, Auld G, Newsom D (2004) Governing through markets: forest certification and the emergence of non-state authority. Yale University Press, New Haven

12. Taylor PL (2005) In the market but not of it: fair trade coffee and forest stewardship council certification as market-based social change. World Dev 33:129-147

13. Muradian R, Pelupessy W (2005) Governing the coffee chain: the role of voluntary regulatory systems. World Dev 33:2029-2044

14. Cramer J, Wissema E, de Bruijne M, Lammers E, Dijk D, Jager $H$, van Bennekom S, Breunesse E, Horster R, van Leenders C, Wonink S, Wolters W, Kip H, Stam H, Faaij A, Kwant K (2007) Testing framework for sustainable biomass. Creative Energy. http://www.fao.org/bioenergy/20536-06144295874a6d8a5da1b5203aa 32916a.pdf. Accessed 21 Sep 2012

15. Kaplinsky R, Morris M (2001) A handbook for value chain research. http://www. srp-guinee.org/download/valuechain-handbook.pdf. Accessed 22 Feb 2013

16. Gereffi G, Humphrey J, Sturgeon T (2005) The governance of global value chains. Rev Int Polit Econ 12:78-104

17. Humphrey J (2006) Global value chains in the agrifood sector: UNIDO working paper. http://www.unido.org/fileadmin/import/60026_01_global_ value_chains_agrifood_sector.pdf. Accessed 22 Feb 2013

18. Ponte S, Gibbon P, Vestergaard J (2011) Governing through standards: an introduction. In: Ponte S, Gibbon P, Vestergaard J (ed) Governing through standards - origins, drivers and limitations. Palgrave Macmillan, Hampshire, pp 1-24

19. Brassett J, Tsingou E (2011) The politics of legitimate global governance. Rev Int Polit Econ 18:1-16

20. Büthe $T$ (2010) Private regulation in the global economy: a (P) review. Bus Polit. doi:10.2202/1469-3569.1328

21. Cashore B (2002) Legitimacy and the privatization of environmental governance: how non-state market-driven (NSMD) governance systems gain rule-making authority. Governance 15:503-529

22. Bernstein S, Cashore B (2007) Can non-state global governance be legitimate? An analytical framework. Regul Govern 1:347-371

23. Mutersbaugh T, Klooster D, Renard M-C, Taylor P (2005) Certifying rural spaces: quality-certified products and rural governance. J Rural Stud 21:381-388

24. Castree N (2008) Neoliberalising nature: the logics of deregulation and reregulation. Environ Plan 40:131-152

25. Klooster D (2010) Standardizing sustainable development? The Forest Stewardship Council's plantation policy review process as neoliberal environmental governance. Geoforum 41:117-129

26. Taylor PL (2005) A fair trade approach to community forest certification? A framework for discussion. J Rural Stud 21:433-447

27. Partzsch $L$ (2011) The legitimacy of biofuel certification. Agric Hum Values 28(3):413-425

28. Vogelpohl T, Hirschl B (2011) Soziale Kriterien in der freiwilligen Zertifizierung von Biokraftstoffen. Ökologisches Wirtschaften 1:30-34

29. Fritz T (2008) Zertifizierung von Agrotreibstoffen - Die Verlängerung des Erdölzeitalters und die Privatisierung des Rechts. http://fdcl-berlin.de/ fileadmin/fdcl/Publikationen/Zertifizierung-von-Agrotreibstoffen-DieVerlaengerung-des-Erdoelzeitalters-und-die-Privatisierung-des-RechtsThomas-Fritz-FDCL.pdf. Accessed 21 Sept 2012

30. Blazejczak J, Edler D (2004) Nachhaltigkeitskriterien aus ökologischer, ökonomischer und sozialer Perspektive - ein interdisziplinärer Ansatz. DIW Vierteljahrshefte zur Wirtschaftsforschung. http://ejournals.duncker-humblot. de/doi/pdf/10.3790/vjh.73.1.10. Accessed 16 Jan 2013

31. Berndes G, Bryngelson D, Sparovek G (2010) Is it possible to avoid bad impacts by using good fuel ethanol. http://www.naturvardsverket.se/ Documents/publikationer/978-91-620-6331-3.pdf. Accessed 21 Sep 2012

32. Novo AL, Jansen K, Slingerland M, Giller K (2010) Biofuel, dairy production and beef in Brazil: competing claims on land use in SP. J Peasant Stud 37(4):769-792

33. Lambin EF, Meyfroidt P (2011) Global land use change, economic globalization, and the looming land scarcity. PNAS 108(9):3465-3472

34. Grau HR, Aide M (2008) Globalization and land-use transitions in Latin America. Ecol Soc 13(2):16

35. Wilkinson J, Reydon B, Sabbato A (2011) Dinâmica do mercado de terras na América Latina: caso do Brasil. FAO/Escritório Regional, Brasilia

36. Al-Riffai P, Dimaranan B, Laborde D (2010) European Union and United States Biofuel Mandates: impacts on world markets. Inter-American Development Bank, technical note no. IDB-TN-191. http://idbdocs.iadb.org/wsdocs/getdocument. aspx?docnum=35529623. Accessed 21 Sep 2012
37. Lapola D, Schaldach R, Alcamo J, Bondeau A, Koch J, Koelking C, Priess J (2010) Indirect land-use changes can overcome carbon savings from biofuels in Brazil. PNAS 107(8):3388-3393

38. Arima EY, Richards P, Walker R, Caldas MM (2011) Statistical confirmation of indirect land use change in the Brazilian Amazon. Environ Res Lett 6:: doi:10.1088/1748-9326/6/2/024010

39. Searchinger $T$, Heimlich $R$, Houghton R, Dong F, Elobeid A, Fabiosa J, Tokgoz S, Haye D, Yu T (2008) Use of US croplands for biofuels increases greenhouse gases through emissions from land-use change. Science 319(2):1238-1240

40. Fargione J, Hill J, Tilman D, Polasky S, Hawthorne P (2008) Land clearing and the biofuel carbon debt. Science 319(2):1235-1238

41. Righelato R, Spracklen DV (2007) Carbon mitigation by biofuels or by saving and restoring forests? Science 317(8):902

42. Global Bioenergy Partnership GBEP (2011) The global bioenergy partnership sustainability indicators for bioenergy. http://www.globalbioenergy.org/ programmeofwork/task-force-on-sustainability/gbep-report-on-sustainabilityindicators-for-bioenergy/en/. Accessed 21 Sept 2012

43. Teixeira de Andrade RM, Miccolis A (2011) Policies and institutional and legal frameworks in the expansion of Brazilian biofuels: CIFOR working paper 71. http://www.cifor.org/publications/pdf_files/WPapers/WP71CIFOR. pdf. Accessed 15 Jan 2013

44. Mendonça ML (2010) Monopólio da Terra no Brasil: impactos da expansão de monocultivos para a produção de agrocombustíveis. Revista Monopolio. Rede Social de Justiça e Direitos Humanos. Comissã o Pastoral da Terra. http://www.social.org.br/revista-monopolio.pdf. Accessed 15 Jan 2013

45. Beduschi-Filho LC (2003) Assentamentos Rurais e Conservação da Natureza: do Estranhamento a Ação Coletiva. FAPESP, São Paulo

46. Empresa de Pesquisa Energética EPE (2011) Análise de Conjuntura dos Biocombustíveis Janeiro 2010 - Dezembro 2010. http://www.epe.gov.br/ Petroleo/Paginas/PaineldeBiocombust\%C3\%ADveis\%E2\%80\%93Boletinsdean \%C3\%A1lisedeconjuntura.aspx?CategorialD. Accessed 21 Sept 2012

47. Freitas FLM, Sparovek G (2009) Sugarcane expansion near to agrarian reform settlements: a case study of Pontal, Brazil. Proceedings of the International Conference on Geo-spatial Solutions for Emergency Management and the 50th Anniversary of the Chinese Academy of Surveying and Mapping, Beijing, 14-16 September 2009. http://www.isprs. org/proceedings/XXXVII/congress/8_pdf/1_WG-VIII-1/17.pdf. Accessed 15 Jan 2013

48. International Sustainability \& Carbon Certification ISCC (2011) Sustainability Requirements for the Production of Biomass. http://www.iscc-system.org/ uploads/media/ISCC_EU_202_Sustainability_Requirements-

Requirements_for_theProduction_of_Biomasse_2.3_01.pdf. Accessed 25 March 2013

49. Roundtable on Sustainable Biofuels RSB (2011) Consolidated RSB EU RED principles and criteria for sustainable biofuel production. http://rsb.epfl.ch/ page-24929-en.html. Accessed 22 Feb 2012

50. Bonsucro (2010) Bonsucro EU production standard. http://www.bonsucro. com/welcome.html. Accessed 22 Feb 2012

51. Database of International Labour Standards ILOLEX (2011). International Labour Organization, Genève. Available via http://www.lo.org/ilolex/english/. Accessed 22 Feb 2012

52. Instituto Observatorio Social IOS (2011) Pacto Nacional pela Erradicação do Trabalho Escravo. http://www.os.org.br/pacto/quem.php. Accessed 22 Feb 2012

53. Secretaria-Geral da Presidência da República (2008) Compromisso Nacional para Aperfeiçoar as Condições de Trabalho na Cana-de-Açucar. http://www. secretariageral.gov.br/.arquivos/imagens-publicacoes/Compromisso_port. pdf. Accessed 22 Feb 2012

54. Santos J (2011) Fiscalização trabalhista agoniza no Brasil. http://www. reporterbrasil.org.br/clipping.php?id=1679. Accessed 22 Feb 2012

55. F.O. Licht GmbH (2009) F.O. Licht's World Ethanol \& Biofuels Report, vol. 8 no. 8. Informa Group PLC, London

56. F.O. Licht GmbH (2010) F.O. Licht's World Ethanol \& Biofuels Report, vol. 9 no. 8. Informa Group PLC, London

57. F.O. Licht GmbH (2011) F.O. Licht's World Ethanol \& Biofuels Report, vol. 10 no. 8. Informa Group PLC, London

58. F.O. Licht GmbH (2012) F.O. Licht's World Ethanol \& Biofuels Report, vol. 10 no. 24. Informa Group PLC, London

59. Solidaridad Network (2012) In the future all sugarcane ethanol will be Bonsucro certified. http://www.solidaridadnetwork.org/\%E2\%80\%9C-future- 
all-sugarcane-ethanol-will-be-bonsucro-certified\%E2\%80\%9D. Accessed 11 Dec 2012

60. Junginger M, van Dam J, Zarrilli S, Mohamed F, Marchal D, Faaij A (2011) Opportunities and barriers for international bioenergy trade. Energy Policy 39(4):2028-2042

61. Walter A, Dolzan P, Quilodrán O, Garcia J, da Silva C, Piacente F, Segerstedt A (2008) A sustainability analysis of the Brazilian ethanol. http://www.global bioenergy.org/uploads/media/0811_Unicamp___A_sustainability_analysis_of_ the_Brazilian_ethanol.pdf. Accessed 21 Sep 2012

62. Walter A (2009) IEA bioenergy task 40 - country report, Brazil. http://www. bioenergytrade.org/reports/countryreports/brazil.html. Accessed 22 Feb 2012

63. Junginger $H$, Jonker J, Faaji A, Cocchi M, Hektor B, Hess R, Heinimö J, Hennig C, Kranzl L, Marchal D, Matzenberger J, Nikolaisen L, Pelkmans L, Rosillo-Calle F, Schouwenberg P, Tromborg E, Walter A (2011) Summary, synthesis and conclusions from IEA bioenergy task 40 country reports on international bioenergy trade. http://www.bioenergytrade.org/downloads/ summary-synthesis-and-conclusions-from-iea-bio.pdf. Accessed 25 March 2013

64. Food and Agriculture Organization of the United Nations FAO (2008) Biofuels: prospects, risks and opportunities. The State of Food and Agriculture, FAO, Rome, p 129. Available via http://www.fao.org/docrep/011/i0100e/i0100e00.htm. Accessed 22 Feb 2012

65. Fernandes BM, Welch CA, Gonçalves EC (2010) Agrofuel policies in Brazil: paradigmatic and territorial disputes. Journal of Peasant Studies 37(4):793-819

66. Bonsucro (2011) Certified members. http://www.bonsucro.com/certified members.html. Accessed 12 Dec 2011

67. Wilkinson J, Herrera S (2010) Biofuels in Brazil: debates and impacts. Journal of Peasant Studies 37(4):749-768

68. Scholtes F (2009) Status quo and prospects of smallholders in the Brazilian sugarcane and ethanol sector: lessons for development and poverty reduction. ZEF working paper series 43. http://www.zef.de/fileadmin/webfiles/downloads/ zef_wp/wp43.pdf. Accessed 25 March 2013

69. Centro de Gestão e Estudos Estratégicos CGEE (2009) Bioetanol combustível: uma oportunidade para o Brasil. http://www.cogen.com.br/paper/2010/ Livro_Bioetanol_Cana_Acucar_2009.pdf. Accessed 21 Sept 2012

70. Fundação Getúlio Vargas FGV (2011) Land prices. http://portal.fgv.br. Accessed 18 Nov 2011

71. Fritz T (2010) Peak soil - die globale Jagd nach Land. FDCL, Berlin

72. Informa Economics FNP (2011) Agrianual online. http://www.agrianual.com br. Accessed 18 Nov 2011

73. Neuburger M (2010) Entwicklungsprobleme des ländlichen Raumes. In: Costa S, Kohlhepp G, Nitschak H, Sangmeister H (ed) Brasilien heute: Geographischer Raum, Politik, Wirtschaft. Kultur. Verfuert, Frankfurt, pp 75-90

74. Instituto Brasileiro de Geografia e Estatística IBGE (2006) Censo Agropecuario. http://www.ibge.gov.br/. Accessed 22 Feb 2012

75. Comissão Pastoral da Terra CPT (2010) Conflitos no Campo Brasil 2010. http://www.cptnacional.org.br/index.php/noticias/12-conflitos/618-conflitosno-campo-brasil-2010. Accessed 21 Sept 2012

doi:10.1186/2192-0567-3-6

Cite this article as: Mohr and Bausch: Social sustainability in certification schemes for biofuel production: an explorative analysis against the background of land use constraints in Brazil. Energy, Sustainability and Society 2013 3:6.

\section{Submit your manuscript to a SpringerOpen ${ }^{\circ}$ journal and benefit from:}

- Convenient online submission

- Rigorous peer review

- Immediate publication on acceptance

- Open access: articles freely available online

- High visibility within the field

- Retaining the copyright to your article

Submit your next manuscript at $\gg$ springeropen.com 